\title{
The longicorn beetle tribe Cerambycini Latreille, 1802 (Coleoptera: Cerambycidae: Cerambycinae) in the fauna of Asia. 6. A new or little-known species of the genus Massicus Pascoe, 1867
}

\section{ЖКуки-дровосеки трибы Cerambycini Latreille, 1802 (Coleoptera: Cerambycidae: Cerambycinae) фауны Азии. 6. Новый и малоизвестные виды рода Massicus Pascoe, 1867}

\author{
Alexandr I. Miroshnikov ${ }^{1,2}$ \\ А.И. Мирошников ${ }^{1,2}$
}

\footnotetext{
${ }^{1}$ Russian Entomological Society, Krasnodar, Russia. E-mail: miroshnikov-ai@yandex.ru

2 Sochi National Park, Moskovskaya str., 21, Sochi 354002, Krasnodar region, Russia

${ }^{1}$ Русское энтомологическое общество, Краснодар, Россия

${ }^{2}$ Сочинский национальный парк, ул. Московская, 21, Сочи 354000, Краснодарский край, Россия
}

KEY WORDS: Coleoptera, Cerambycidae, Cerambycini, Massicus, new or little-known species, Peninsular Malaysia, Borneo.

КЛЮЧЕВЫЕ СЛОВА: Coleoptera, Cerambycidae, Cerambycini, Massicus, новый и малоизвестные виды, полуостров Малакка, Борнео.

ABSTRACT. A new species, Massicus regius sp.n., that has been mixed with M. pascoei (J. Thomson, 1857) for a long time, is described from Peninsular Malaysia and Borneo. Massicus fryi Gahan, 1890 and M. ivani Miroshnikov, 2017 are recorded from Western Malaysia, as generally from Indochina, for the first time. The data on the distribution of $M$. pascoei are discussed. New records of M. intricatus (Pascoe, 1866) and M. valentinae Miroshnikov, 2017 from Western Malaysia, and M.punctulipennis Holzschuh, 2018 from southern Vietnam are presented. The lectotype of $M$. intricatus is designated.

РЕЗЮМЕ. ОПисан новый вид Massicus regius sp.n. с Малайского полуострова и Борнео, который долгое время смешивался с M. pascoei (J. Thomson, 1857). Massicus fryi Gahan, 1890 и M. ivani Miroshnikov, 2017 впервые отмечены в Западной Малайзии, как и в целом в Индокитае. Рассмотрены данные о распространении M. pascoei. Приведены новые находки M. intricatus (Pascoe, 1866) и M. valentinae Miroshnikov, 2017 в Западной Малайзии, а $M$. punctulipennis Holzschuh, 2018 - в южном Вьетнаме. Обозначен лектотип M. intricatus.

Until now, many groups of the tribe Cerambycini remain poorly studied in various aspects. The genus Massicus Pascoe, 1867 is no exception in this regard.
The present paper describes a new species that has been mixed with the type species of the genus, $M$. pascoei (J. Thomson, 1857) for a long time. Addittionally, it provides new records of several little-known species expanding or clarifying their distribution areas to some extent, as well as presents other new data.

The material treated in this work belongs to the following institutional and private collections: $\mathrm{BMNH}-$ Natural History Museum (London, United Kingdom); IRSN - Institut Royal de Sciences naturelles de Belgique(Bruxelles); MNHN - Muséum national d'Histoire naturelle (Paris, France); NHMD — Natural History Museum of Denmark, University of Copenhagen (Copenhagen, Denmark); cAM - collection of Alexandr Miroshnikov (Krasnodar, Russia); cCH - collection of Carolus Holzschuh(Villach, Austria); cDH - collection of Daniel Heffern (Houston, USA); cLD - collection of Luboš Dembický (Brno, Czech Republic).

\section{Genus Massicus Pascoe, 1867}

Massicus Pascoe, 1867: 319 [name replacement for Conotho$\operatorname{rax}$ J. Thomson, 1864, non Jeckel, 1854 (Curculionidae)]. Lacordaire, 1868: 260; Gemminger, 1872: 2802; Gahan, 1906: 129; Aurivillius, 1912: 55; Gressitt, Rondon, 1970: 59; Lee, 1982: 27; Kusama, Takakuwa, 1984: 252; Hüdepohl, 1990: 60; Catalogue..., 2010: 161; Heffern, 2013: 10; Nga et al., 2014: 435; Kariyanna et al., 2017: 31; Miroshnikov, 2017: 224.

Mallambyx Bates, 1873: 152 (Pachydissus subgen.).

Mallambyx: Ganglbauer, 1889: 473; Winkler, 1929: 1141; Matsushita, 1933: 243; Mitono, 1940: 82; Plavilstshikov, 1940: 79, 635;

How to cite this article: Miroshnikov A.I. 2019. The longicorn beetle tribe Cerambycini Latreille, 1802 (Coleoptera: Cerambycidae: Cerambycinae) in the fauna of Asia. 6. A new or little-known species of the genus Massicus Pascoe, 1867 // Russian Entomol. J. Vol.28. No.3. P.269-281. doi: 10.15298/rusentj.28.3.06 
Gressitt, 1951: 135; Kojima, Hayashi, 1969: 47; Tsherepanov, 1981: 22 Type species: Cerambyx pascoei J. Thomson, 1857, by monotypy.

Massicus pascoei (J. Thomson, 1857)

Figs 1-2, 4-6, 11, 13-14, 17, 20, $23,27,31,33,37,41,45,48$.

Cerambyx pascoei Thomson, 1857: 122, pl. 14, fig. 6. Type locality: "Inde" (according to the original description) or "India or." (according to the label of the holotype) (see also Remarks below).

Conothorax pascoei: Thomson, 1864: 230 ("Malasia").

Massicus [pascoei]: Pascoe, 1867: 319.

Massicus pascoei: Lacordaire, 1868: 260 ("Malasie"); Gemminger, 1872: 2802 ("Archip. ind."); Gahan, 1906: 129 ("Malay Peninsula"); Aurivillius, 1912: 55 ("Malacca"); Heffern, 2013: 10 ("E. India; W Malaysia; SE Asia [probably within the limits of Indochina]"); Kariyanna et al., 2017: 31 ("India \& Malaysia")

MATERIAL. Holotype by monotypy, o (MNHN) (Figs 5-6), "India or.", "Ex Musæo James Thomson", "444", "Conothorax Thoms. s.c.230. (Cône, Thorax.), Massicus Pasc. An. M. n. h. XIX, 319.", "Pascoei Thoms. Type, Malas. Ind.?", "Th. / Type" (Fig. 4); $20^{7}$ (cAM) (Fig. 1), Laos, Houa Phan Prov., Phou Pane Mt., $20^{\circ} 11$ N / $104^{\circ} 00^{\prime} \mathrm{E}, 2060 \mathrm{~m}, 06.2017$ (local collector); 2 + (cAM) (Fig. 2), same locality, but taken on 05.2017; 19 (BMNH) (Fig. 3), "Malacca", "Ex Mus Parry", "Fry Coll. 1905.100.", “43 ... [illegible further on]", "NHMUK 013386288" (see Remarks below).

REMARKS. Apparently this species was described from a single female originating from India [Thomson, 1857: 122: "Patrie: Inde"]. However, in the subsequent Thomson's work [1864: 230] it was given as from "Malasia" without any comments. On one labels of the holotype is indicated "India or.", while on the other — "... Malas. Ind.?".

I have studied two males and two females from northeastern Laos that are very similar to the holotype and that I identify here as $M$. pascoei. Some specimens from China (Yunnan) and northern Myanmar, known to me only from their photographs belong to this species too.

At the same time, almost all specimens I have revised from Western Malaysia, externally similar to M. pascoei, are actually a new species described below.

Only one female (Fig. 3) from the old collections at the BMNH with the "Malacca" label almost certainly belongs to M. pascoei. However, its geographical label is possibly erroneous, and therefore it cannot be considered indisputable evidence of the distribution of $M$. pascoei in Western Malaysia.

MORPHOLOGICAL NOTES. Body length 52.2-58.8 $\mathrm{mm}$, humeral width $14.5-15.7 \mathrm{~mm}$, thereby the holotype is $57.3 \mathrm{~mm}$ and $15.7 \mathrm{~mm}$, respectively.

Judging from some photographs, the body length of this species can reach about $61 \mathrm{~mm}$.

DISTRIBUTION. Eastern India, China (Yunnan), Myanmar, Laos; almost without any doubt, Vietnam and Thailand; ?Western Malaysia.

Massicus regius Miroshnikov, sp.n.

Figs 7-10, 12, 15-16, 18-19, 21-22, 24-26, 28-30, $32,34,36,38-39,42-43,46-47,49-50$.

Massicus pascoei (non J. Thomson, 1857): Hayashi, 1975: 174 pl. 1, fig. 9 (W Malaysia, Pahang, Cameron Highlands, Tanah Rata); Miroshnikov, 2017: 225, fig. 414 (pronotum).

?Massicus pascoei (non J. Thomson, 1857): Schwarzer, 1926: 14 (Sumatra, Tambang Sawah); Abang, 2003: 28 (Sarawak); Heffern, 2013: 10 (Borneo)

MATERIAL. Holotype, $\sigma^{7}$ (cAM) (Fig. 7), W Malaysia, Pahang, Cameron Highlands, Tanah Rata, 01.2019 (local collector) Paratypes: 19 (cAM) (Fig. 9), same label as holotype; $10^{7}$ (NHMD),

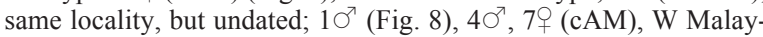
sia, Perak, Tapah Hills, 500-700 m, 01.2019 (local collector); $10^{\circ}$ (BMNH), "Malay Penin: Perak F.M.S., ex coll. Perak Mus., C. Warang, 19[?]", "Massicus (Conothorax, Thomson) pascoei, J.
Thomson", "Ex F.M.S. Museum B.M. 1955-354", "NHMUK 013386253"; $10^{7}$ (BMNH), "Malay Penin: Perak F.M.S., ex coll. Perak Mus., C. Warang, 19[?]”, "Ex F.M.S. Museum B.M. 1955354", "NHMUK 013386280"; $10^{7}$ (IRSN), "Coll. Nonfried. Borneo".

DIAGNOSIS. This new species is very similar to $M$. pascoei, but differs clearly by the less convex eyes, more weakly developed at least on the ventral side of the head, as in Figs 15-16, 18-19 (cf. Figs 14, 17); the length ratio of isthmus between the lower lobes of the eyes and the transverse diameter of the lower eye lobe, as in Figs 15-16, 18-19 (cf. Figs 14, 17); the obliterated or at least distinctly less coarse sculpture of the submentum, but clearer dense puncturation, as in Figs 15-16, 18-19 (cf. Figs 14, 17); the shorter median groove on the vertex, as in Figs 7-9, 32 (cf. Figs 1-2, $5,31)$; the ratio width of the pronotum at base and at apex in the male, as in Figs 7-8 (cf. Fig. 1); the presence of rough, distinct, sparse punctures (besides a small dense puncturation) on several basal antennomeres of the male, starting from antennomere 3; on the average a larger body; the structure of the genitalia, mainly in the male.

Additionally, in Massicus regius sp.n., compared to $M$. pascoei, the pronotum is usually less convex, with two more or less well-developed spots of dense, light setae (besides numerous sparse setae) on its sides, as in Fig. 10 (cf. Fig. 11); the prosternal process at the very apex and dorsally is usually narrower and, accordingly, the apical tubercles are more closely spaced, as in Figs 24-26, 28-30 (cf. Figs 6, 23, 27); the mesosternal process in the vast majority of cases is narrower, as in Figs 24-25, 28-30 (cf. Figs 6, 23, 27); the antennal tubercles are usually stronger, often transverse, at least so in the male, as in Fig. 12 (cf. Fig. 13); the sculpture of male antennomere 1 is usually coarser, as in Fig. 32 (cf. Fig. $31)$; the constriction behind the temples in the male is less sharp, as a rule, as in Figs 15-16 (cf. Fig. 14); the apical external angle of the elytra is often more obtuse or even nearly rounded; the recumbent light setation of the submentum is usually more strongly developed, as in Figs 15-16, 18-19 (cf. Figs 14, 17); and the antennae of the female are usually slightly shorter.

The new species can also be compared to $M$. ivani and $M$. valentinae, but is distinguished very distinctly from both, partly like from $M$. pascoei, in the completely different shape of the prosternal process at the apex and dorsally, as in Figs 24-26, 28-30 (cf. Figs 52-54); the wider submentum, its obliterated or at least clearly less coarse sculpture; the less convex pronotum, its somewhat peculiar sculpture and usually also shape; the usually stronger antennal tubercles, often transverse, at least so in the male; the more strongly protruding apical external angle of antennomere 1, the coarser sculpture of this antennomere in the male, including the presence of well-expressed rough and coarse transverse folds in the basal part predominatly on the inner side, as in Fig. 32; the presence of rough, distinct, sparse punctures (besides a small dense puncturation) on several basal antennomeres of the male, starting from antennomere 3; the longer male antennae, as a rule, and, respectively, the more strongly elongated some antennomeres; on the average a larger body; the structure of the genitalia. Besides this, $M$. regius sp.n. differs from $M$. ivani by the slenderer and clearly less strongly inflated antennomeres 3-5 of the male in the apical part, while it differs from $M$. valentinae by the features of the recumbent light setation of the pronotum, including the much less numerous setae in the middle part of the disc between the clearly wider longitudinal stripes.

DESCRIPTION. Body length $55.6-76.2$ or $59.2-74.3$ $\mathrm{mm}$, humeral width $14.8-19.95$ or $17-20.1 \mathrm{~mm}$ in male and 


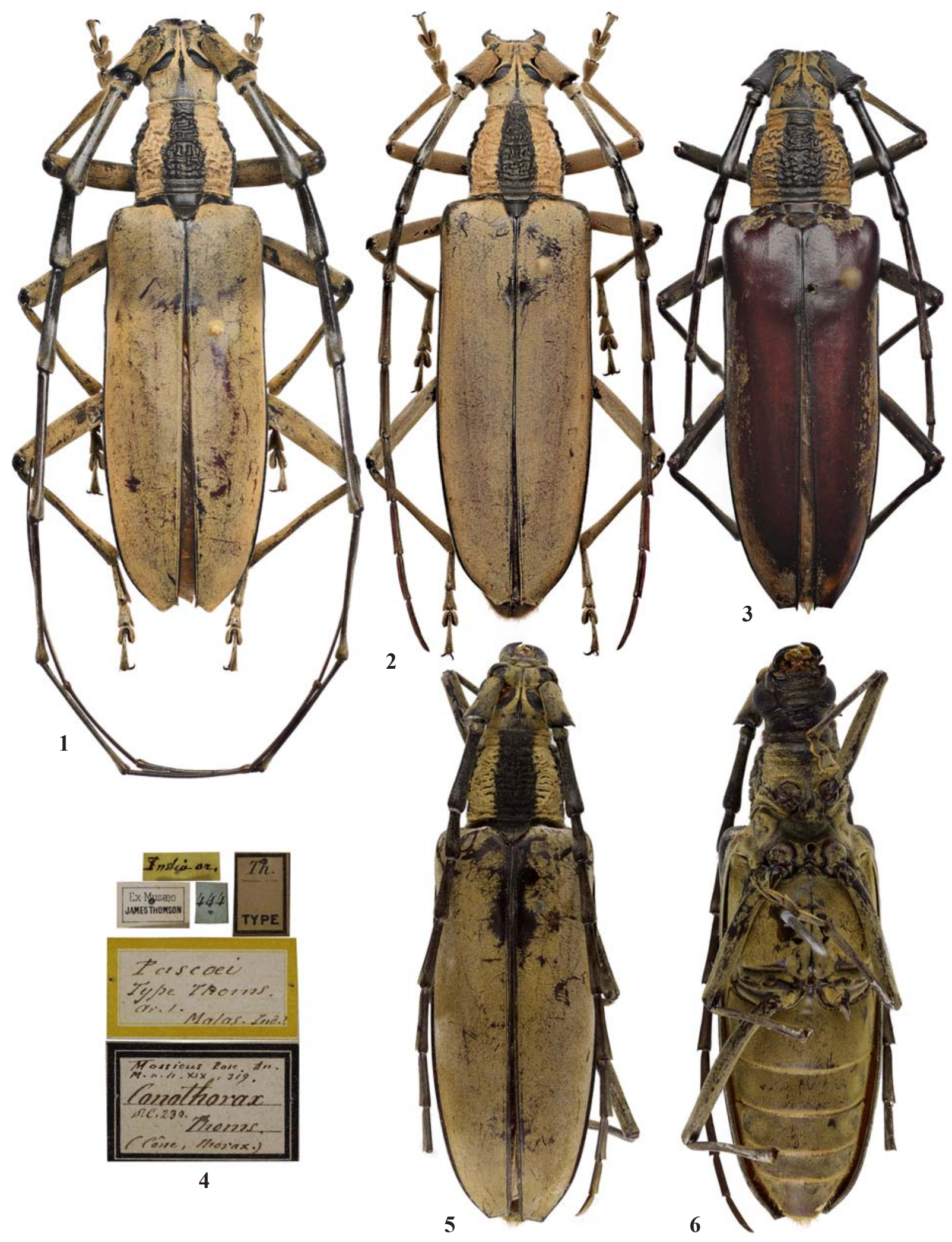

Figs 1-6. Massicus spp., habitus and labels: 1-2, 4-6-M. pascoei; 3 - M. ?pascoei (from "Malacca"); 4-6 — holotype (photographs by Azadeh Taghavian); 1-3, 5 - dorsal view; 6 - ventral view.

Pис. 1-6. Massicus spp., общий вид и этикетки: 1-2, 4-6-M. pascoei; 3 - M. ?pascoei (“Malacca”); 4-6 — голотип (фотографии Азаде Тагвьян); 1-3, 5 - сверху; 6 - снизу. 


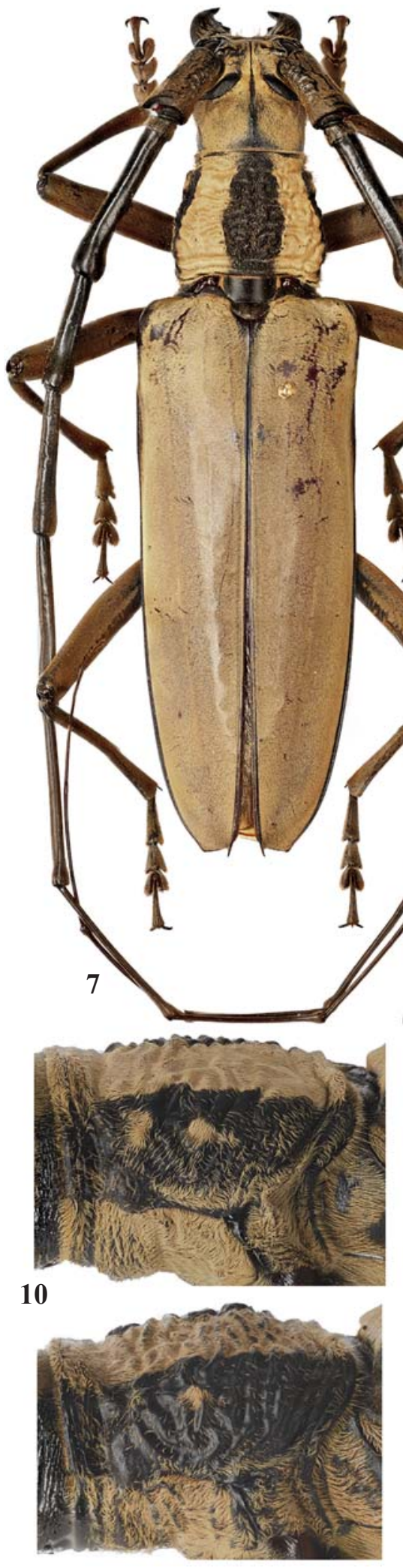

11

Figs 7-13. Massicus spp.: 7-10, 12 - M. regius sp.n.; 11, 13-M. pascoei; 7, 12 - holotype; 8 -10 - paratypes; 7-8, 10-13 - males; 9 - female; 7-9 - habitus, dorsal view; 10-11 - pronotum, lateral view; 12-13 - antennal tubercles, dorsal view.

Рис. 7-13. Massicus spp.: 7-10, 12 - M. regius sp.n.; 11, 13 - M. pascoei; 7, 12 - голотип; 8-10 - паратипы; 7-8, 10-13 -самцы; 9- самка; 7-9 - общий вид, сверху; 10-11 - переднеспинка, сбоку; 12-13 - усиковые бугорки, сверху. 

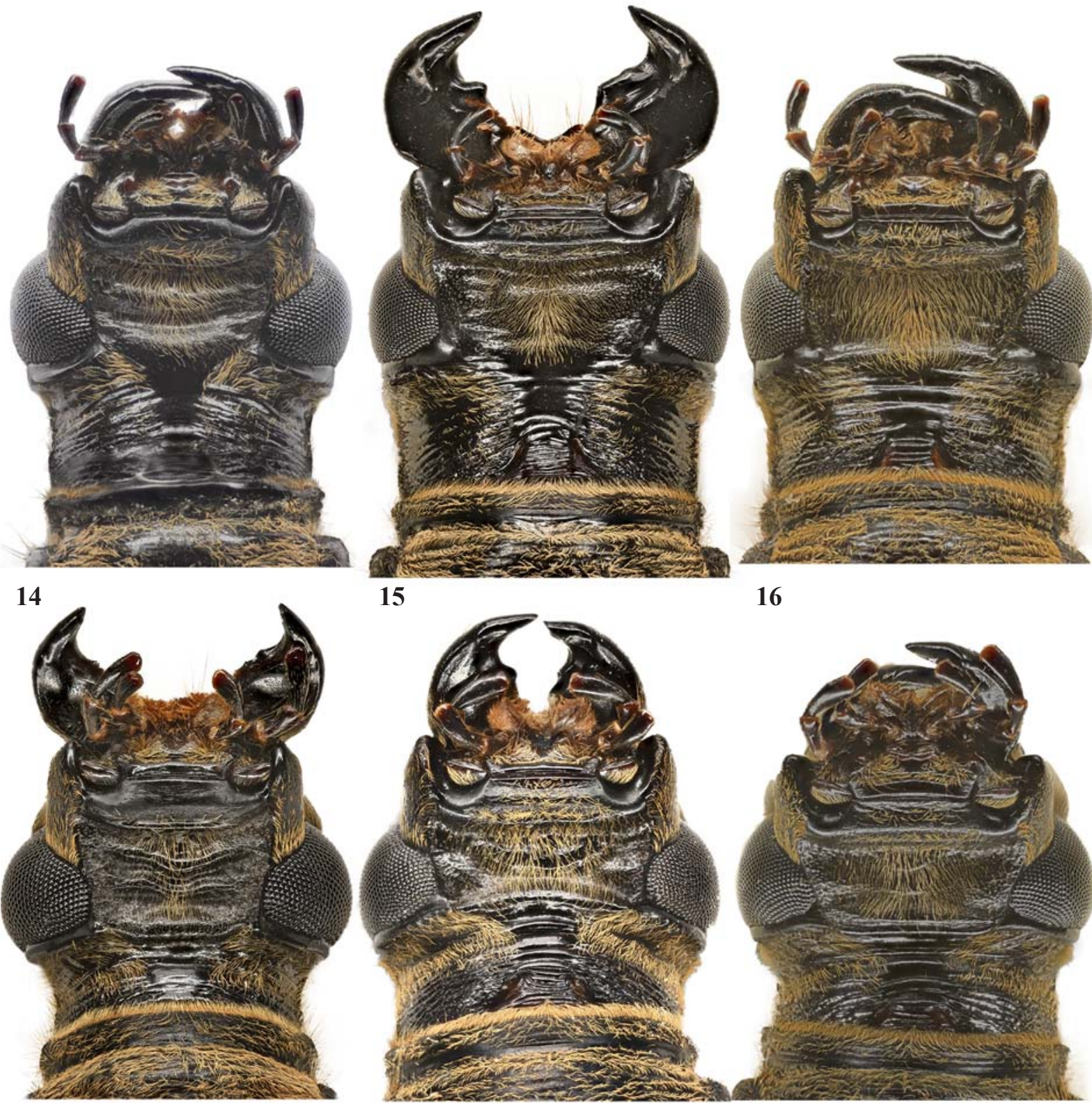

15

16

17
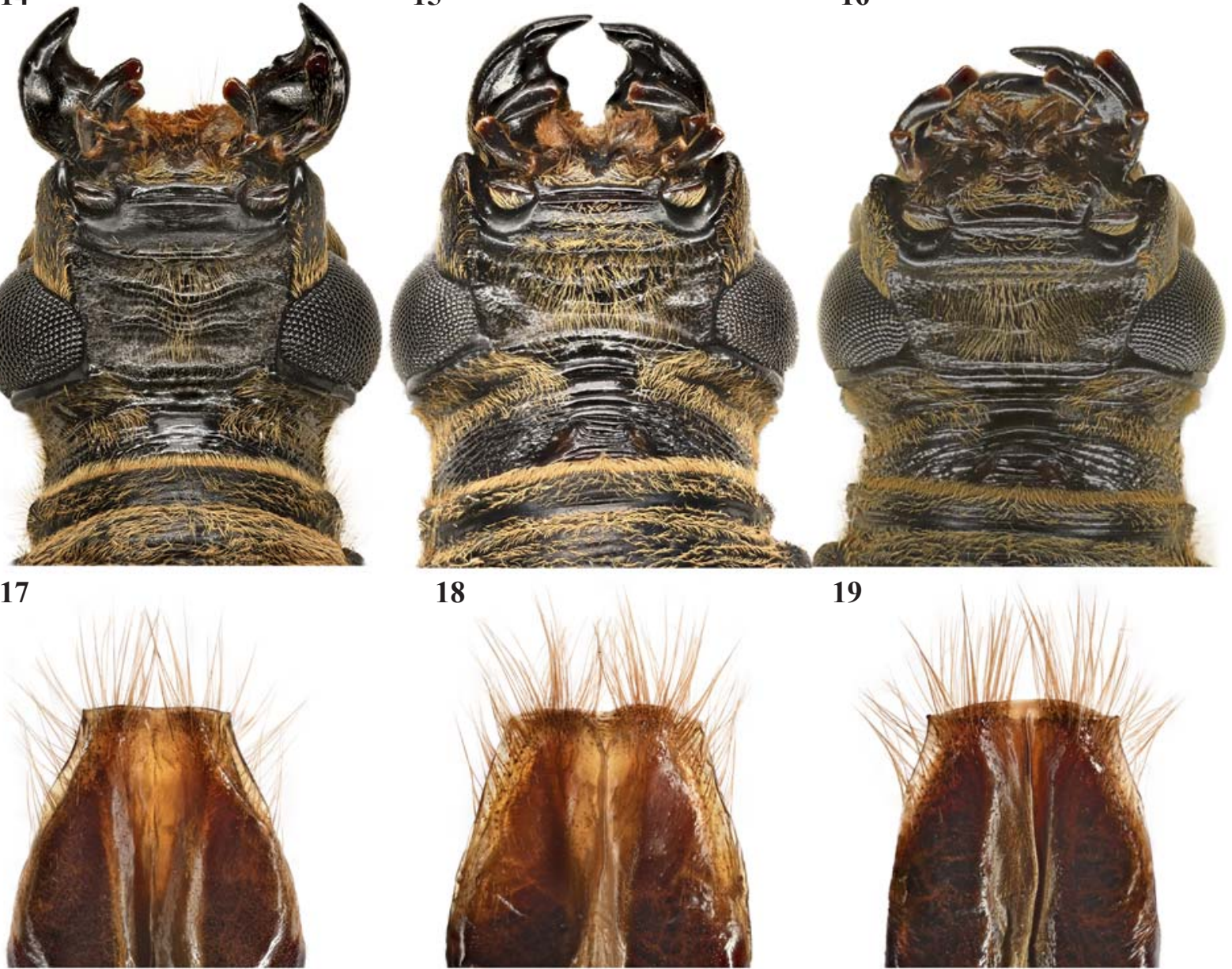

20

18

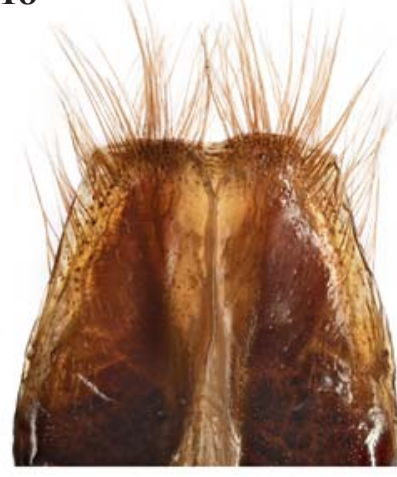

21
19

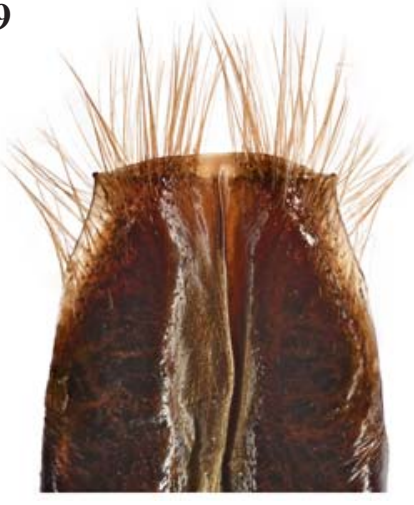

22

Figs 14-22. Massicus spp.: 14, 17, $20-$ M. pascoei; 15-16, 18-19, 21-22 - M. regius sp.n.; 15 - holotype; 16, 18-19, 21-22paratypes; 14-16 - males; 17-22 - females; 14-19 - head, ventral view; 20-22 - tergite 8, dorsal view.

Рис. 14-22. Massicus spp.: 14, 17, $20-$ M. pascoei; 15-16, 18-19, 21-22 - M. regius sp.n.; 15 — голотип; 16, 18-19, 21-22 паратипы; 14-16 - самцы; 17-22 - самки; 14-19 - голова, снизу; 20-22 - 8-й тергит, сверху. 
female, respectively, thereby holotype one of largest in length (see also Remarks below). Head, pronotum, scutellum, basal antennomeres, partly legs black; remaining parts mainly combines dark reddish brown and reddish brown tones; sometimes venter partly or mostly, as well as elytra partly black or black-brown.

Head with very well-developed antennal tubercles, as a rule, thereby usually in large specimens, especially of males, transverse ones (while in M. pascoei, antennal tubercles never being transverse); with a distinct, narrow, median groove between bases of antennae, as well as with a wider one between eyes and partly on vertex; genae long; eyes moderately convex, thereby isthmus between their lower lobes 2.3 3.4 times as long as transverse diameter of lower eye lobe (while in M. pascoei, isthmus between lower lobes of eyes only 1.7-1.9 times as long as transverse diameter of lower eye lobe); submentum very wide, with individual, rough, transverse folds or without ones, but with distinct dense punctures, at least partly so (while in M. pascoei, submentum with individual, coarse or very coarse, transverse folds, but only with weak, partly poorly-visible punctures); neck ventrally and gula with more or less sharp transverse folds; antennae of male much longer than body, reaching beyond apex of elytra by antennomere 7 or rarely 8 , in female barely/slightly not reaching the apex of elytra or extending beyond by last antennomere; length ratio of antennomeres 1-11 in male (holotype taken as an example), $50: 10: 78: 55: 72: 87: 88$ $: 86: 74: 71: 153$, in female (one of the paratypes taken as an example), $36: 8: 51: 34: 41: 45: 40: 34: 30: 29: 42$; antennomere 1 of male with coarse or very coarse sculpture, including transverse folds mainly on inner side and ventrally, in female with more or less rough folds mostly in places, like in male, apical external angle in both sexes very sharply protruding; antennomere 2 very clearly or strongly transverse; in male, antennomere 3 and several subsequent antennomeres, in addition to small dense puncturation, with somewhat peculiar, rough, sparse punctures, to varying degrees distinct, depending on angle of view (while in M. pascoei, antennomere 3 and subsequent antennomeres without rough sparse punctures, only with a small, dense, partly heterogeneous puncturation); apical external angle of antennomeres 610 with a sharp denticle, most developed and sharper on antennomeres 8-10; last antennomere sharpened apically.

Pronotum 1.11-1.21 or 1.2-1.25 times as wide as long, at base $1.2-1.26$ or $1.37-1.46$ times as wide as apex in male and female, respectively (while in male of M. pascoei, pronotum at base 1.33-1.34 times as wide as apex, at least in specimens I have studied); slightly convex; on disc with a more or less coarse, mainly transverse folds.

Scutellum almost uniformly rounded towards apex, starting from base.

Elytra very clearly narrowed towards apex behind the middle, 2.52-2.59 times as long as humeral width; with a very small dense puncturation; apical external angle rounded or obtusely angular; sutural angle drawn into a more or less long tooth.
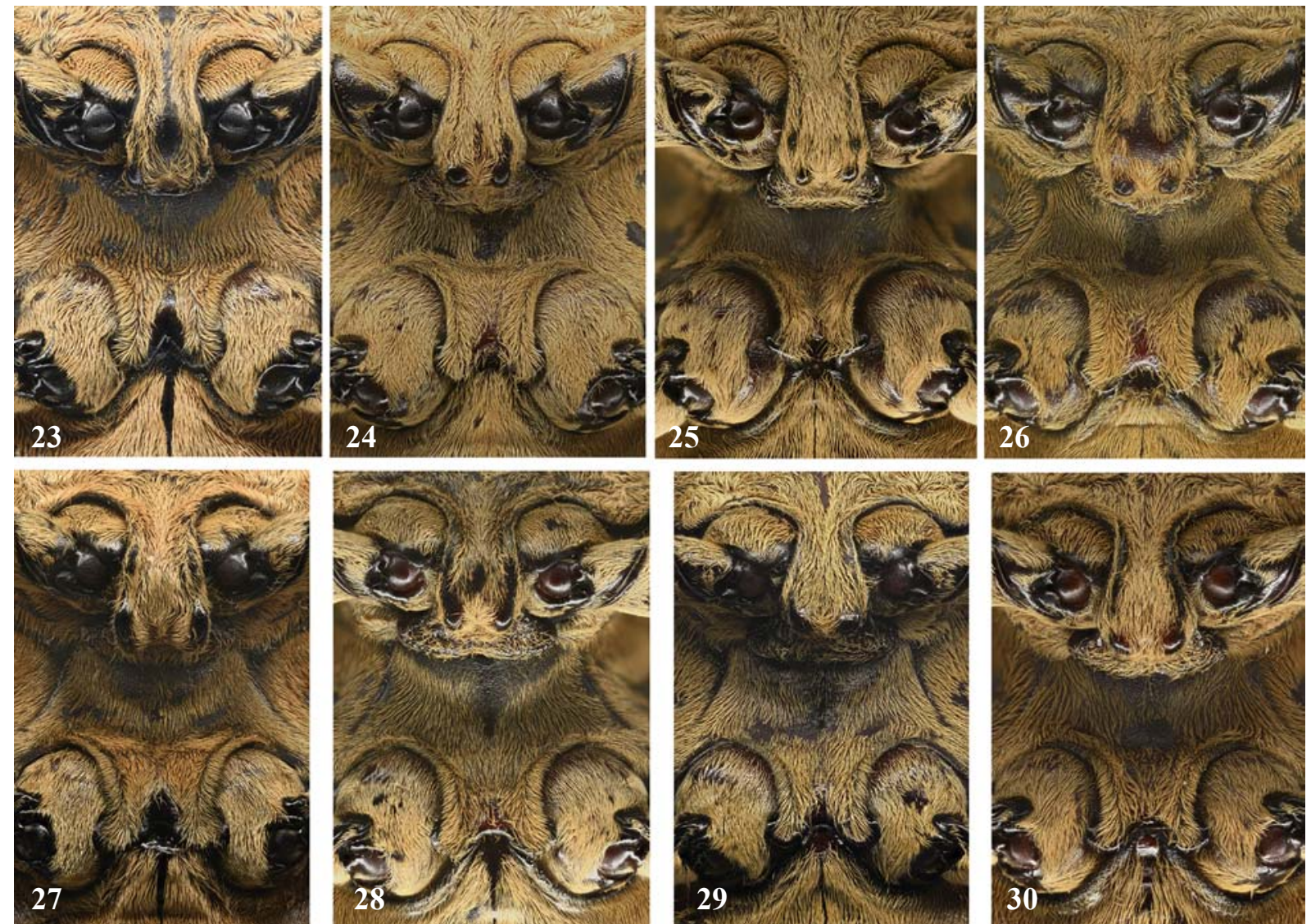

Figs 23-30. Massicus spp., pro- and mesosternal processes: 23, 27 - M. pascoei; 24-26, 28-30 - M. regius sp.n., paratypes; 23-26 males; $27-30$ - females.

Рис. 23-30. Massicus spp., отростки про- и мезостернума: 23, 27 - M. pascoei; 24-26, 28-30 - M. regius sp.n., паратипы; 2326 - самцы; 27-30 - самки. 


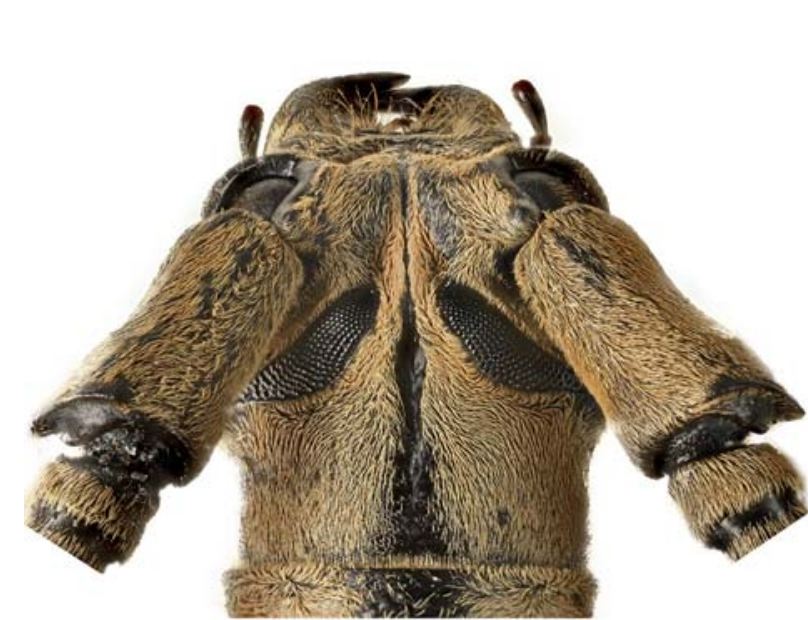

31

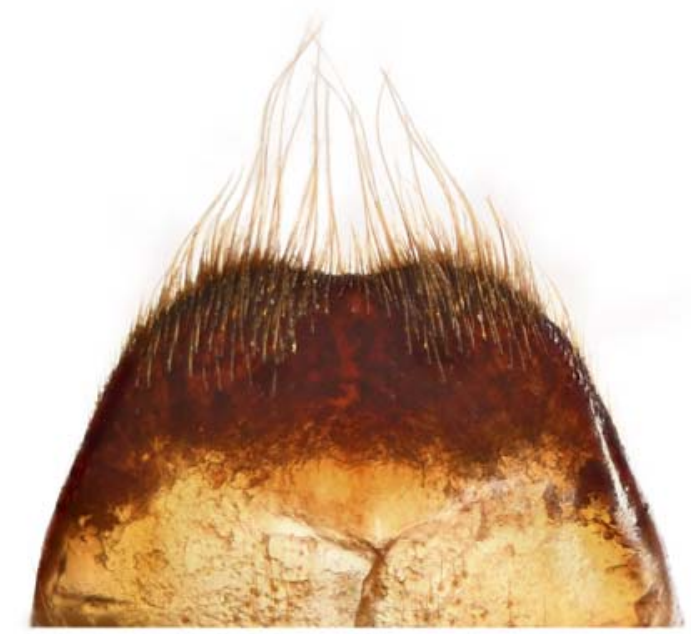

33

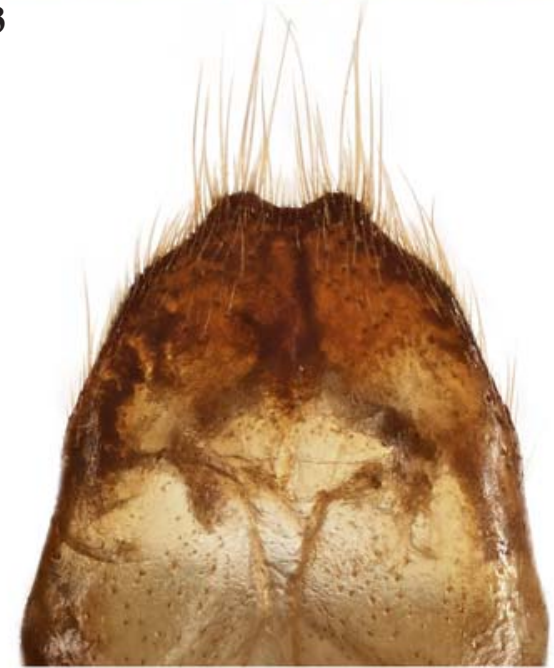

35

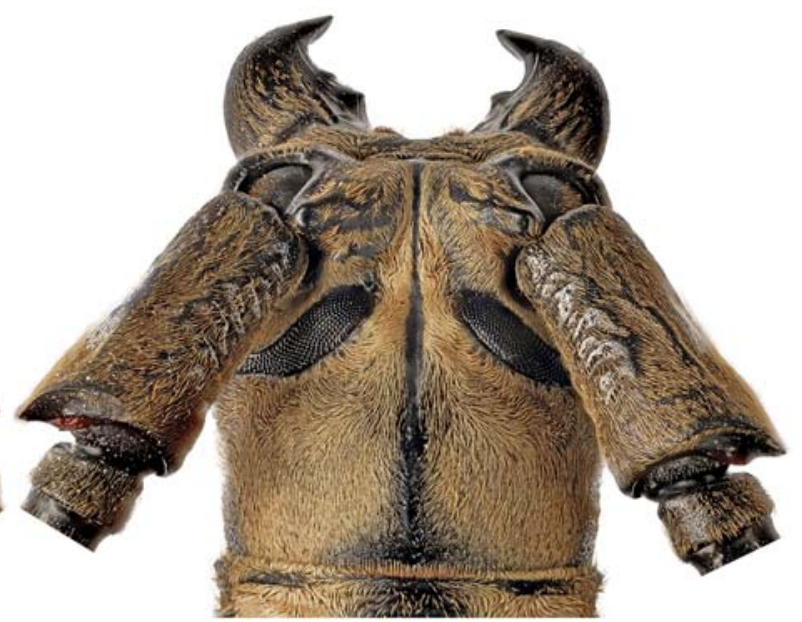

32

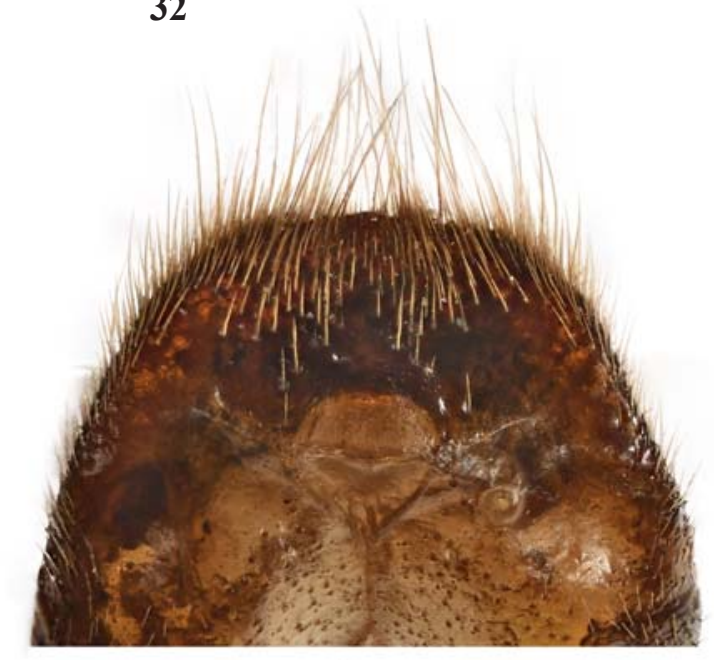

34

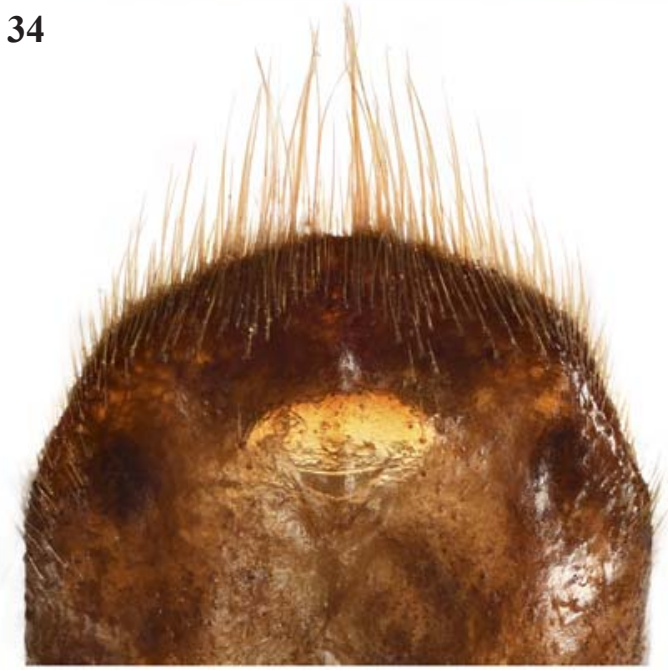

36

Figs 31-36. Massicus spp., males: 31, $33-$ M. pascoei; 32, 34, 36 - M. regius sp.n.; $35-$ M. trilineatus; 32 - holotype; $34,36-$ paratypes; 31-32 - head and antennomeres 1-2, dorsal view; 33-36 - tergite 8, dorsal view.

Рис. 31-36. Massicus spp., самцы: 31, 33 - M. pascoei; 32, 34, 36 - M. regius sp.n.; 35 - M. trilineatus; 32 — голотип; 34, 36 паратипы; 31-32 - голова и 1-2-й членики усиков, сверху; 33-36 - 8-й тергит, сверху. 
A.I. Miroshnikov
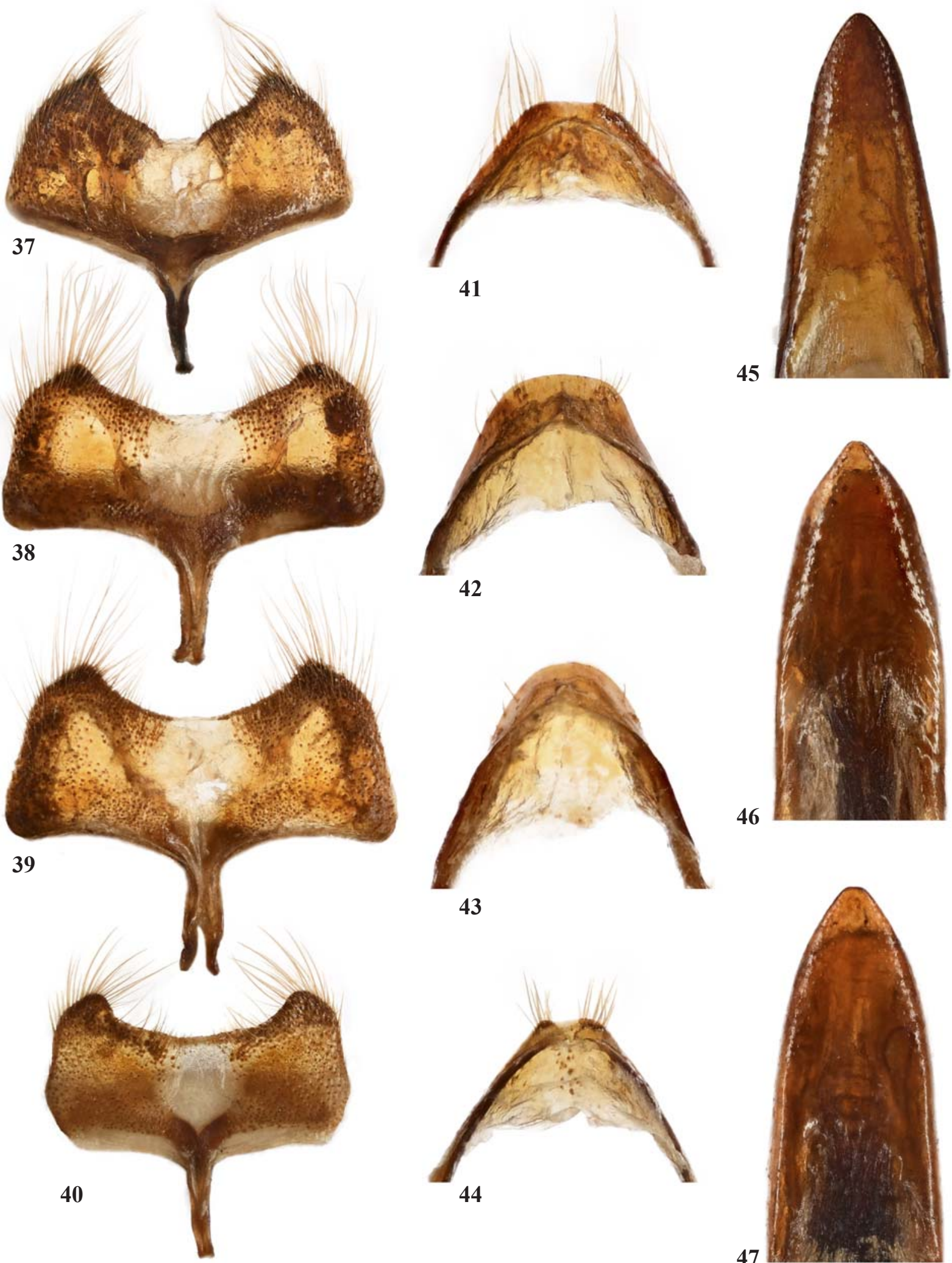

42
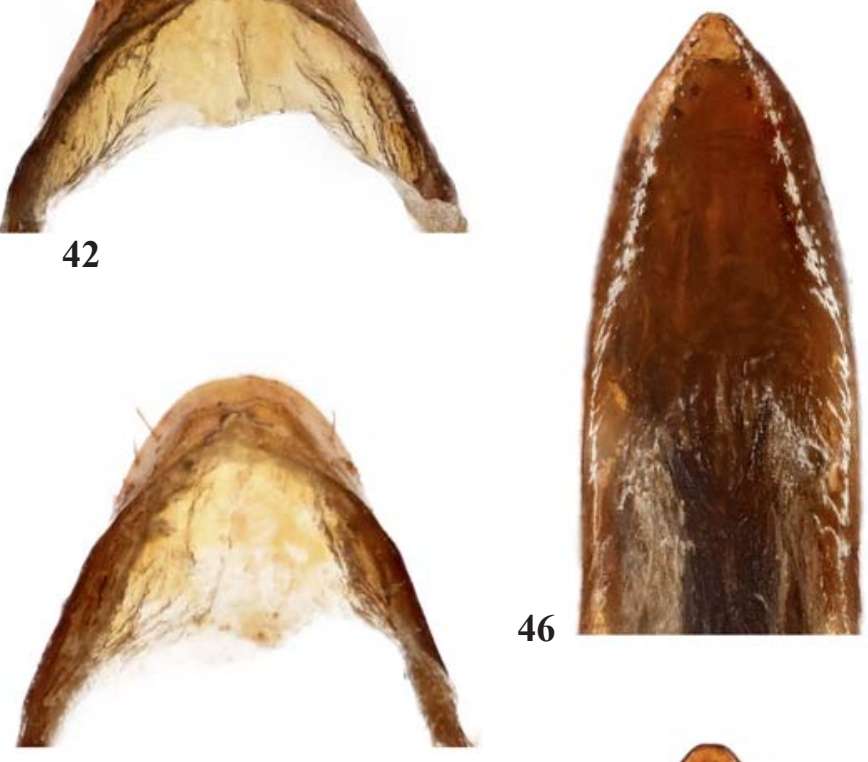

46
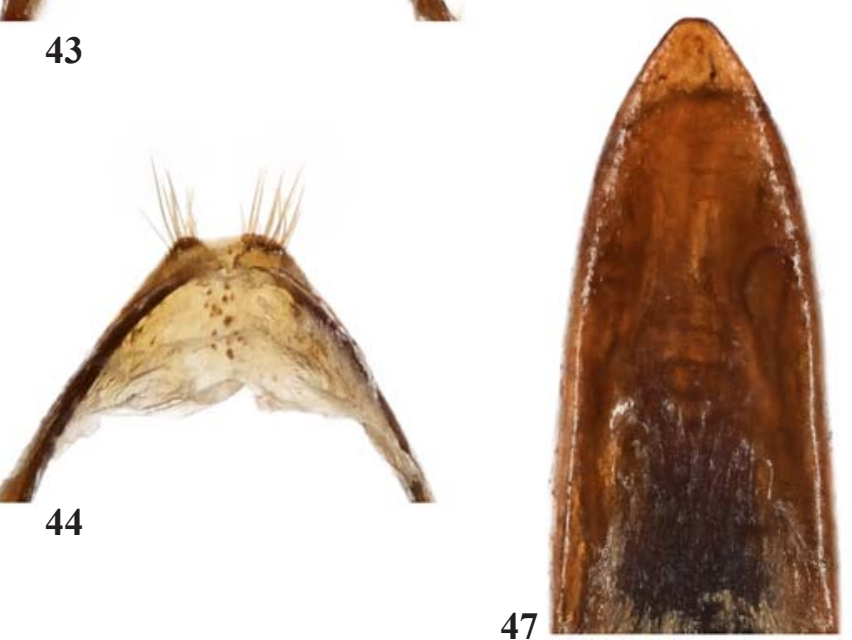

Figs 37-47. Massicus spp., male genitalia: 37, 41, 45-M. pascoei; 38-39, 42-43, 46-47-M. regius sp.n., paratypes; 40, 44 - M. trilineatus; 37-40 — sternite 8, dorsal view; 41-44 — apical part of dorsal arc (of tergite 9), dorsal view; 45-47 — apical part of penis, ventral view.

Рис. 37-47. Massicus spp., гениталии самца: 37, 41, 45 - M. pascoei; 38-39, 42-43, 46-47 - M. regius sp.n., паратипы; 40, $44-$ M. trilineatus; 37-40 - 8-й стернит, сверху; 41-44 — вершинная часть дорсальной дуги (9-го тергита), сверху; 45-47 — вершинная часть пениса, снизу. 
Prosternum in apical one-third tuberculiform elevated, with rough transverse folds, in middle part with coarser, partly irregular folds; prosternal process noticeably or very clearly broadened towards apex dorsally, but in about apical one-quarter or one-fifth usually distinctly narrowed towards very apex dorsally, with two tubercles on sides apically and dorsally; mesosternal process between coxae distinctly or barely wider than prosternal process; metasternum and sternites with a small dense puncturation; metasternum with a sharp median groove; last (visible) sternite at apex in male broadly truncate or almost truncate, in female broadly slightly rounded, sometimes with a poorly-visible emargination; last (visible) tergite at apex in both sexes noticeably or very clearly, sometimes barely emarginate.

Legs moderately long; metatarsomere 1 subequal to metatarsomeres 2 and 3 combined.

Recumbent dense setation, like in $M$. pascoei, yellow tones, entirely or almost completely covering elytra, antennomeres 1 and 2, legs, most of head dorsally and venter, on pronotal disc forming two very wide, symmetrical, longitudinal strips on sides; head, pronotum on disc and laterally, most of antennomeres in apical part, metasternum, apex of abdomen, legs mainly on trochanters with more or less long, erect or suberect, sparse or individual, thin setae.

Genitalia (Figs 21-22, 34, 36, 38-39, 42-43, 46-47, 49-50). In male, tergite 8 broadly rounded or subtruncate apically, without emargination, as in Figs 34, 36, sternite 8 with a moderately deep oblong-oval emargination apically, as in Figs 38-39, dorsal arc (tergite 9) with more or less weakly developed, few, erect setae at apex, as in Figs 42-43 (while in male of $M$. pascoei, tergite 8 clearly emarginate at apex, as in Fig. 33, sternite 8 apically quite deeply and angularly emarginate, as in Fig. 37, dorsal arc (tergite 9) with well-developed, relatively numerous, erect setae apically, as in Fig. 41); apical part of penis, compared to $M$. pascoei (Fig. 45), clearly wider, somewhat peculiarly narrowed towards the very apex, as in Figs 46-47; each paramera mainly on inner half predominantly in basal part with a strong, oblique, pocket-shaped, peculiar elevation, as indicated by arrows in Figs 49-50, but along external margin almost the entire length with a narrow bordure, as in Figs 49-50 (while in $M$. pascoei, each paramera on inner half without oblique pocket-shaped elevation, as in Fig. 48, but on external side mostly in middle part with a bordure being obtusangularly broadened towards inner side, as indicated by arrows in Fig. 48) (in M. pascoei, at least structure of parameres and dorsal arc (tergite 9) most similar to those of M. trilineatus (Pic, 1933), Figs 44, 51; see also Figs 35, 40 for comparison); tergite 8 of female moderately narrowed towards apex, as in Figs 21-22 (while in M. pascoei, tergite 8 of female in apical part strongly narrowed towards apex, as in Fig. 20) (see also Remarks below).

REMARKS. Among all males in the type series only one male is relatively small, while the vast majority of males there are $66.3 \mathrm{~mm}$ and larger, up to the maximum length.

In addition to the above-mentioned differences in the genitalia between M. regius sp.n. and M. pascoei, it must be noted that these species are also distinguished clearly in structure of the endophallus. However, I would have preferred to consider this question at a later date.

ETYMOLOGY. The formation of the name of this new species is related to its magnificent habitus and one of the largest sizes among the congeners.

DISTRIBUTION. Peninsular Malaysia; Borneo; ?Sumatra.
Massicus ivani Miroshnikov, 2017

Figs 52-55.

Massicus ivani Miroshnikov, 2017: 226. Type locality: E Malaysia, Sabah, Keningau Distr., Trus Madi Mt. (according to the original description and the label of the holotype).

MATERIAL. 1 ㅇ (BMNH) (Fig. 55), "Malaya: Kutu Hill. A.S. Corbet. iii.1931", "B[ukit]. Kutu, Mar[ch]. 1931", "A.S. Corbet coll. B.M.1948-587.", "NHMUK 013386290", Massicus ivani Miroshnikov, 2017, det. A. Miroshnikov 2019.

REMARKS. This species has hitherto been known only from Borneo [Miroshnikov, 2017].

Based on the material studied, M. ivani is being recorded here from Western Malaysia, as generally from Indochina, for the first time.

MORPHOLOGICAL NOTES. The female from Malacca is smaller than the female paratype, while its recumbent dense setation is paler than in both type specimens. The body length of this female is $58.5 \mathrm{~mm}$ and the humeral width is $15.8 \mathrm{~mm}$.

\section{Massicus valentinae Miroshnikov, 2017}

Fig. 56.

Massicus valentinae Miroshnikov, 2017: 224. Type locality: W Malaysia, Pahang, Cameron Highlands, Tanah Rata (according to the original description and the label of the holotype).

MATERIAL. 19 (cAM) (Fig. 56), W Malaysia, Perak, Tapah Hills, 500-700 m, 01.2019 (local collector); 19 (cAM), W Malaysia, Pahang, Cameron Highlands, Tanah Rata, 01.2019 (local collector).

REMARKS. This species has hitherto been known only from two localities in Pahang, Western Malaysia [Miroshnikov, 2017].

Based on the material studied, M. valentinae is being recorded here from Perak, Western Malaysia for the first time.

MORPHOLOGICAL NOTES. The female from Perak is largest. Its body length is $61.7 \mathrm{~mm}$ and the humeral width is $16.6 \mathrm{~mm}$.

\section{Massicus fryi Gahan, 1890 Figs 57-59.}

Massicus fryi Gahan, 1890: 260. Type locality: Borneo (according to the original description). Heffern, 2013: 10 (Borneo; ?Thailand, ?Myanmar)

MATERIAL. Holotype by monotypy, ơ (BMNH) (Fig. 57), "Malaya, Massicus fryi Gahan, Type", "Fry Coll. 1905.100.", "Massicus fryi Gahan / Type", "Type" (Fig. 58); $10^{7}$ (cAM) (Fig. 59), W Malaysia, Perak, Tapah Hills, 05.2018 (local collector); 10', 1 우 (cDH) (photographs), E Malaysia, Sabah, Crocker Range, 13.03.1999 (local collector); $10^{7}$ (unknown collection) (photograph), "Malaysia”.

REMARKS. Until now, this species was reliably known only Borneo [Gahan, 1890; Heffern, 2013; personal communication of Mr. Daniel J. Heffern], while it is noted with a question mark from Thailand and Myanmar [Heffern, 2013].

Based on the material studied, $M$. fryi is reliably recorded here from Western Malaysia, as generally from Indochina, for the first time.

MORPHOLOGICAL NOTES. The body length of the holotype male and male from Malacca is 51 or $56.2 \mathrm{~mm}$, the humeral width is 13 or $13.7 \mathrm{~mm}$, respectively.

The body length of Bornean male and female is about 67 $\mathrm{mm}$ (personal communication of Mr. Daniel J. Heffern).

The antennae of male are not less than twice as long as body, usually even longer, in the female subequal to body length; antennomer 1 of female with a very coarse sculpture, like in the male. 

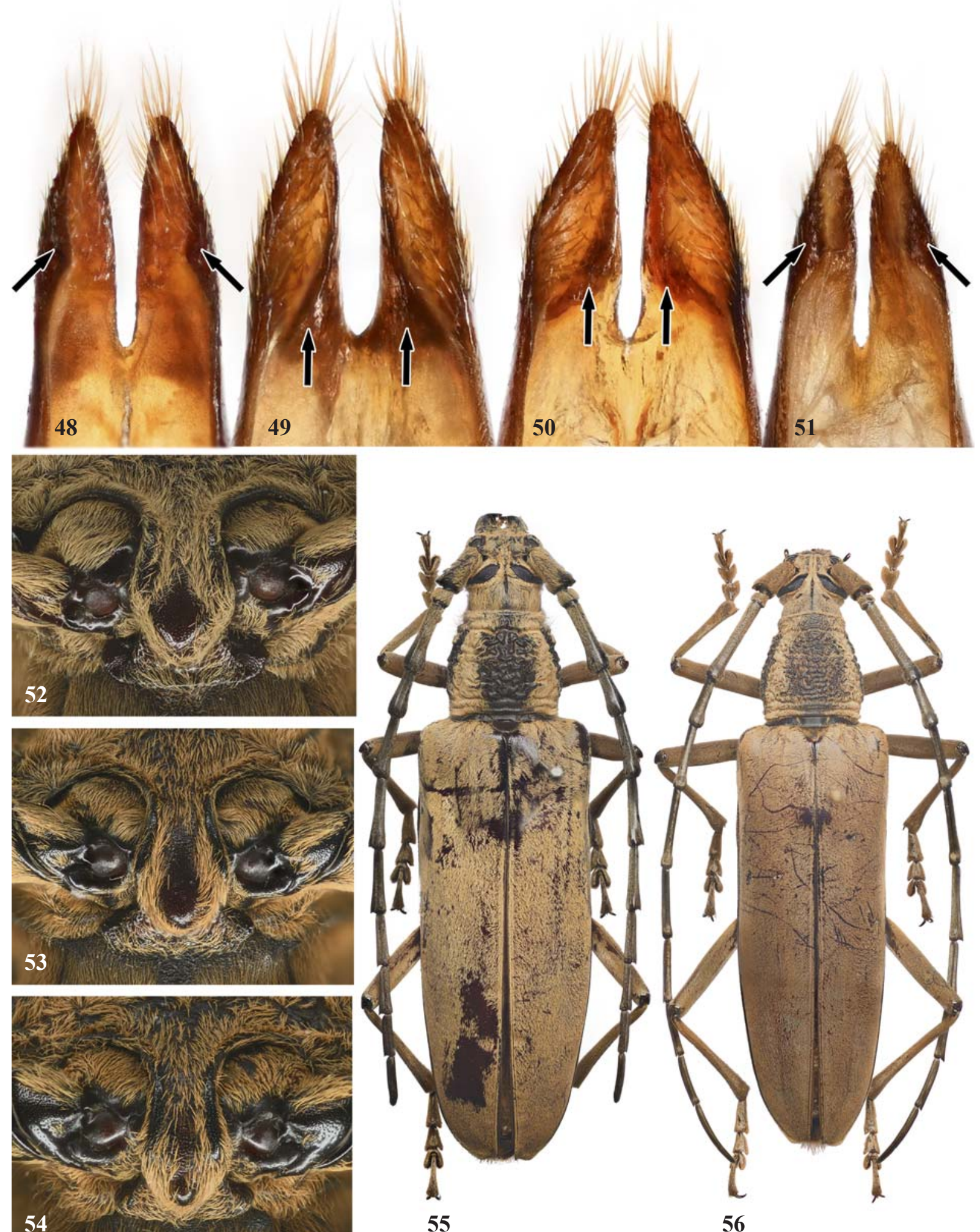

Figs 48-56. Massicus spp.: 48 - M. pascoei; 49-50-M. regius sp.n., paratypes; $51-$ M. trilineatus; 52-55 - M. ivani (52, $55-$ female from Western Malaysia ; 53 - paratype female; 54 - holotype male); 56 - M. valentinae, female; $48-51$ - apical part of tegmen, ventral view; 52-54 - prosternal process; 55-56 - habitus, dorsal view.

Pис. 48-56. Massicus spp.: 48 - M. pascoei; 49-50 - M. regius sp.n., паратипы; 51 - M. trilineatus; 52-55 - M. ivani (52, 55 самка из Западной Малайзии; 53 - паратип, самка; 54 - голотип, самец); 56 - M. valentinae, самка; 48-51 — вершинная часть тегмена, снизу; 52-54 - отросток простернума; 55-56 - общий вид, сверху. 


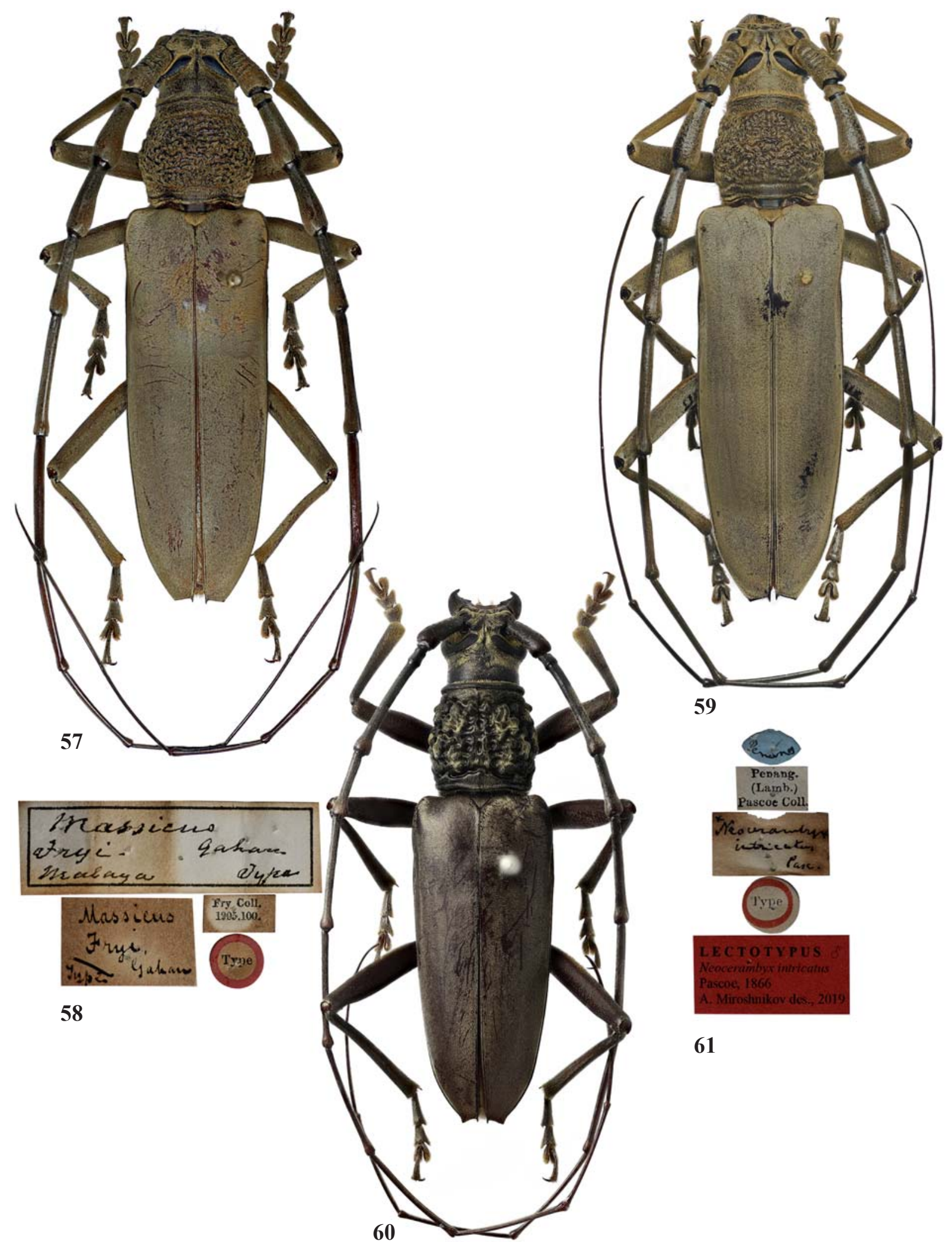

Figs 57-61. Massicus spp., males, habitus, dorsal view, and labels: 57-59-M. fryi (57-58 - holotype; 59 - specimen from Western Malaysia); 60-61 - M. intricatus, lectotype.

Рис. 57-61. Massicus spp., самцы, общий вид, сверху, и этикетки: 57-59 - M. fryi (57-58 — голотип; 59 — экз. из Западной Малайзии); 60-61 - M. intricatus, лектотип. 
Massicus intricatus (Pascoe, 1866) Figs 60-61.

Neocerambyx? intricatus Pascoe, 1866: 527. Type locality: [W Malaysia] "Island of Penang" (according to the original description) or "Penang" (according to the label of the holotype).

Neocerambyx intricatus: Gemminger, 1872: 2798; Aurivillius, 1912: 46.

Massicus intricatus: Hüdepohl, 1990: 249.

MATERIAL. Lectotype, $\sigma^{7}$, here designated (BMNH) (Fig. 60), "Penang", "Penang. (Lamb.) Pascoe Coll.", "Neocerambyx intricatus Pasc.", "Type", Lectotypus $\sigma^{7}$ Neocerambyx intricatus Pascoe, 1866, A. Miroshnikov des., 2019 (Fig. 61); paralectotype, $+(\mathrm{BMNH})$, same geographical labels, Paralectotypus + Neocerambyx intricatus Pascoe, 1866, A. Miroshnikov des., 2019; 10 (cLD), W Malaysia, Perak, Banjaran Bintang, Bukit Berapit (Talping), 11-12.03.1997, leg. I. Jeniš; 207, 1 ( (cLD), $1 \sigma^{\top}$ (cAM ex cLD), same locality, but taken on 20-23.02.1997, leg. Ivo Jeniš ; $1 \sigma^{7}$ (cAM ex cLD), same labels; $1 \sigma^{7}$ (cLD), W Malaysia, Perak, Banjaran Titi Wangsa, Fraser's Hill, 9.03.1997, leg. I. Jeniš; 1 우 (cAM ex cLD), W Malaysia, Pahang, Benom Mts., $15 \mathrm{~km} \mathrm{E}$ Kampong Dong, 300-1000 m, 3.53N / 102.01E, 24.03-15.04.1998, leg. L. Dembický, P.Pacholátko.

REMARKS. Until now, this species was known only from two type specimens (male and female) described from "Island of Penang", Western Malaysia [Pascoe, 1866].

Based on the material studied, $M$. intricatus is recorded here from the precise localities in Perak and Pahang, Western Malaysia for the first time.

MORPHOLOGICAL NOTES. Body length 26.8-38 mm, humeral width $6.8-10.4 \mathrm{~mm}$, thereby the lectotype is the largest.

Massicus punctulipennis Holzschuh, 2018

Massicus punctulipennis Holzschuh, 2018: 87. Type locality: S Vietnam, Play $\mathrm{Cu}$ (according to the original description).

MATERIAL. Holotype, + (cCH) (photograph); 19 (cLD), S Vietnam, $40 \mathrm{~km} \mathrm{NW}$ of An Khe, Buon Luoi, 14.10N / 108.30E, 620-750 m, 28.03-12.04.1995, leg. L. Dembický, P.Pacholátko.

REMARKS. This species was described from a single female, its body length being $32 \mathrm{~mm}$ [Holzschuh, 2018]. I have also examined one female from southern Vietnam (see above) with a body length of $29.3 \mathrm{~mm}$ and a humeral width of $6.6 \mathrm{~mm}$.

Acknowledgements. I am very grateful to Maxwell V.L. Barclay and Michael F. Geiser (BMNH), Thierry Deuve and Azadeh Taghavian (MNHN), Alain Drumont (IRSN), Alexey Yu. Solodovnikov and Sree Gayathree Selvantharan (NHMD) for the opportunity to study the museum material, to Luboš Dembický (Brno, Czech Republic) who has provided some specimens from his private collection. I am deeply indebted again to Alexey Yu. Solodovnikov who helped a lot in my prompt receipt of the material for study, to Daniel J. Heffern (Houston, USA), Denis G. Kasatkin (Rostov-onDon, Russia), Florence Trus (IRSN), again Luboš Dembický, Alain Drumont and Azadeh Taghavian for the helpful provision of some pictures and/or valuable information. I give special thanks to my wife Tatiana P.Miroshnikova for having rendered great help in the preparation of almost all photographs and to Kirill V. Makarov (Moscow Pedagogical State University, Russia) who has also helped in the preparation of the several pictures.

\section{References}

Abang F. 2003. A checklist of the longhorn beetles (Cerambycidae: Cerambycinae) of Sarawak // Serangga. Vol.8. Nos 1-2. P.25-31.
Aurivillius Chr. 1912. Cerambycidae: Cerambycinae // Coleopterorum Catalogus, auspiciis et auxilio W. Junk, editus a S. Schenkling. Pars 39. Berlin: W. Junk. P.3-574.

Bates H.W. 1873. On the Longicorn Coleoptera of Japan // The Annals and Magazine of Natural History. Ser.4. Vol.12. No.68. P.148-156.

Catalogue of Palaearctic Coleoptera. Vol.6. Chrysomeloidea / I. Lobl, A. Smetana (eds.). 2010. Stenstrup: Apollo Books. 924 pp.

Gahan C.J. 1890. Notes on Longicorn Coleoptera of the group Cerambycinae, with descriptions of new genera and species // The Annals and Magazine of Natural History. Ser.6. Vol.6. No.33. P.247-261.

Gahan C.J. 1906. Cerambycidae // The fauna of British India, including Ceylon and Burma. Coleoptera. Vol.1. London: Taylor and Francis. xviii +329 pp.

Ganglbauer L. 1889. Longicornes. Cerambycidae // S.A. Marseul de, (ed.). Catalogue synonymique et geographique des Coleoptères de l'Ancien-Monde, Europe et contrees limitrophes en Afrique et en Asie // L'Abeille, Journal d'Entomologie. 1888. T. 25. P. 465-480.

Gemminger M. 1872. Cerambycidae // Gemminger M., Harold E. Catalogus Coleopterorum hucusque descriptorum synonymicus et systematicus. T.9. Scolytidae, Brenthidae, Anthotribidae, Cerambycidae. Monachii: E.H. Gummi (G. Beck). P.2751$2988+11 \mathrm{pp}$.

Gressitt J.L. 1951. Longicorn beetles of China // P. Lepesme (ed.). Longicornia. Etudes et notes sur les Longicornes. Vol.2. Paris: Paul Lechevalier. 667 pp. +22 pls

Gressitt J.L., Rondon J.A. 1970. Cerambycids of Laos (Disteniidae, Prioninae, Philinae, Aseminae, Lepturinae, Cerambycinae) // Gressitt J.L., Rondon J.A., Breuning S. von. Cerambycid-beetles of Laos. Pacific Insects Monograph. Vol.24. Honolulu: Entomology Department, Bernice P.Bishop Museum. P.1-314.

Hayashi M. 1975. On some longicorn beetles from Borneo and Malaya, chiefly from the entomological result of Dr. M. Hayashi's S.E. Asian Expedition in 1970 (Col.: Cerambycidae) // Bulletin of the Osaka Jonan Women's Junior College. Vol.10. P.167-209. 6 pls.

Heffern D.J. 2013. A Catalog and Bibliography of Longhorned Beetles from Borneo (Coleoptera: Cerambycidae, Disteniidae and Vesperidae). Electronic Version, 2013.1. 107 p. Available at: https:/www.zin.ru/animalia/coleoptera/pdf/ heffern_2013_borneo_catalog.pdf (accessed 31 August 2019).

Holzschuh $\bar{C} .201 \overline{8}$. Zur Synonymie und neue Arten von Bockkäfern der Unterfamilie Cerambycinae aus Asien (Coleoptera, Cerambycidae) // Les Cahiers Magellanes. No.29. P.80-96.

Hüdepohl K.-E. 1990. The longhorn beetles of the Philippines. Part II // Entomofauna. Zeitschrift fur Entomologie. Bd.11. Hf.3/1. S.45-102.

Kariyanna B., Mohan M., Gupta R., Vitali F. 2017. The checklist of longhorn beetles (Coleoptera: Cerambycidae) from India // Zootaxa. Vol.4345. No.1. P.1-317.

Kojima K., Hayashi M. 1969. [Longicorn Beetles] // Insects' life in Japan. Vol.1. Osaka: Hoikusha Publishing. 295 pp. [In Japanese]

Kusama K., Takakuwa M. 1984. The longicorn-beetles of Japan in color. Kodansha (Tokyo): Japanese Society of Coleopterology. 565 pp. +96 pls. [in Japanese].

Lacordaire J.T. 1868. Histoire naturelle des insectes. Genera des Coleoptères, ou expose methodique et critique de tous les genres proposes jusqu'ici dans cet ordre d'insectes. T. 8. [1869]. Paris: Librairie encyclopedique de Roret. $552 \mathrm{pp}$

Lee S.-M. 1982. Longicorn Beetles of Korea (Coleoptera: Cerambycidae) // Insecta Koreana. Ser. 1. Seoul: Editorial Commitee of Insecta Koreana. 101 pp.

Matsushita M. 1933. Beitrag zur Kenntnis der Cerambyciden des japanischen Reichs // Journal of the Faculty of Agriculture of the Hokkaido Imperial University. Vol.34. Pt.2. P.157-445 + pls. $1-5+\mathrm{i}-\mathrm{X}$.

Miroshnikov A.I. 2017. The longicorn beetle tribe Cerambycini Latreille, 1802 (Coleoptera: Cerambycidae: Cerambycinae) in the fauna of Asia. 1. New or little-known taxa, mainly from Indochina and Borneo, with reviews of some genera // Caucasian Entomological Bulletin. Vol.13. No.2. P.161-233, color pls 1- 
6. DOI: 10.23885/1814-3326-2017-13-2-161-233

Mitono T. 1940. 94. Cerambycidae // Catalogus Coleopterorum Japonicorum. Pars 8. Taihoku: Noda-Syobo. 283 pp.

Nga C.T.Q., Long K.D., Thinh T.H. 2014. New records of the tribe Cerambycini (Coleoptera: Cerambycidae: Cerambycinae) from Vietnam // Tap Chi Sinh Hoc. Vol.36. No.4. P.428-443.

Pascoe F.P.1866. Catalogue of Longicorn Coleoptera collected in the Island of Penang by James Lamb, Esq. (Part II.) // The Proceedings of the Scientific Meetings of the Zoological Society of London. P.504-537+ pls. XLI-XLIII.

Pascoe F.P.1867. Characters of some new genera of the Coleopterous family Cerambycidae // The Annals and Magazine of Natural History. Ser.3. Vol.19. No.113. P.307-319.

Plavilstshchikov N.N. 1940. Fauna SSSR. Nasekomye zhestkokrylye. T.22. Zhuki-drovoseki (Ch. 2) [Fauna of the USSR. Insects, Coleoptera. Vol.22. Longhorn beetles (Pt.2)]. Moscow - Le- ningrad: Academy of Sciences of the USSR. 785 pp. [In Russian]

Schwarzer B. 1926. Fauna sumatrensis. (Beitrag Nr. 12). Cerambycidae (Col.) // Entomologische Mitteilungen. Bd.15. Nr.1. S.1418.

Thomson J. 1857. Description de trente-trois espèces de coléoptères // Archives Entomologiques. T.1. P.109-127.

Thomson J. 1864. Systema Cerambycidarum ou exposé de tous les genres compris dans la famille des Cérambycides et familles limitrophes. Livres 1-3. Liége: H. Dessain. 352 p.

Tsherepanov A.I. 1981. Usachi Severnoy Azii [Cerambycids of Northern Asia (Cerambycinae)]. Novosibirsk: Nauka. 216 pp. [In Russian]

Winkler A. 1929. Phytophaga. Cerambycidae // Catalogus Coleopterorum regionis palaearcticae. Pars 9-10. Wien: Albert Winkler. P.1135-1226. 